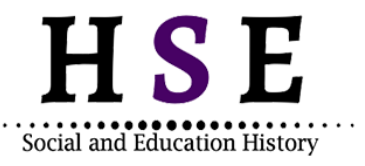

Social and Education History
Hipatia Press

www.hipatiapress.com

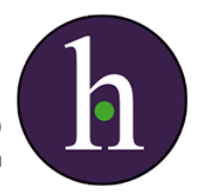

\title{
Jane Addams, Coherence in Uncertain Times: a Political Entrepreneurship in Social Work
}

Patricia Melgar $^{1}$, Teresa Plaja ${ }^{2}$, Ariadna Munté ${ }^{2}$, Gisela Redondo ${ }^{3}$

1) Universitat de Girona

2) Universitat de Barcelona

3) Universitat Rovira i Virgili

Date of publication: $23^{\text {th }}$ October 2021

Edition period: October 2021-February 2022

To cite this article: Melgar, P.; Plaja, T.; Munté, A., \& Redondo, G. (2021). Jane Addams, coherence in Uncertain Times: a political entrepreneurship in social work. Social and Education History, 10(3), 362-379.

https://dx.doi.org/10.17583/hse.8771

To link this article: http://dx.doi.org/10.17583/hse.8771

PLEASE SCROLL DOWN FOR ARTICLE

The terms and conditions of use are related to the Open Journal System and to Creative Commons Attribution License (CCAL). 


\section{Jane Addams, Coherence in Uncertain Times: a Political Entrepreneurship in Social Work}

Patricia Melgar

Universitat de Girona

Teresa Plaja

Universitat de Barcelona
Ariadna Munté

Universitat de Barcelona

Gisela Redondo

Universitat Rovira i Virgili

\section{Abstract}

Since its inception, social work has promoted the defense of human rights and social justice. Doing so has also implied having an influence in the political arena. Although, in some contexts, participation in the political arena of social workers is limited. Based on an analysis of the figure of Jane Addams, using a bibliographic analysis, this study shows the role that social work can play in changing policies and the importance of being coherent with personal values, as well as engaging in equal dialogue using human rights and social justice as a starting point. Jane Addams became a political entrepreneur in fields such as the struggle for women's rights, the rights of immigrants, the fight against child labor exploitation and the quest for peace. This positioning had negative repercussions on her public image, although she was finally awarded the Nobel Peace Prize.

Keywords: Jane Addams, social justice, social work, history, political entrepreneurship 


\section{Jane Addams, Coherencia en Tiempos Inciertos: un Emprendimiento Político en el Trabajo Social}

Patricia Melgar

Universitat de Girona

Teresa Plaja

Universitat de Barcelona
Ariadna Munté

Universitat de Barcelona

Gisela Redondo

Universitat Rovira i Virgili

\section{Resumen}

Desde sus inicios, el trabajo social ha promovido la defensa de los derechos humanos y la justicia social. Hacerlo ha implicado también tener una influencia en el ámbito político. Aunque, en algunos contextos, la participación en la arena política de los y las trabajadoras sociales es limitada. A partir del análisis de la figura de Jane Addams, mediante un análisis bibliográfico, este estudio muestra el papel que puede desempeñar el trabajo social en el cambio de políticas y la importancia de ser coherente con los valores personales, así como de entablar un diálogo igualitario tomando como punto de partida los derechos humanos y la justicia social. Jane Addams se convirtió en una emprendedora política en campos como la lucha por los derechos de la mujer, los derechos de los inmigrantes, la lucha contra la explotación laboral infantil y la búsqueda de la paz. Este posicionamiento repercutió negativamente en su imagen pública, aunque finalmente fue galardonada con el Premio Nobel de la Paz.

Palabras clave: Jane Addams, justicia social, trabajo social, historia, emprendimiento político 


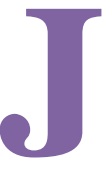

ane Addams is known for being a pioneer in the field of social work. Like her contemporary Mary Richmond, she provided a scientific basis for the assistance activity based on research and the definition of evidence-based procedures (Addams, 1910; Richmond, 1917). Mary Richmond focused her work on a family-centered approach, developing social casework theoretically. On the other hand, Jane Addams focused on the development of group and community social action. Jane Addams was co-founder of Hull House in Chicago, where the interventions were carried out based on the tandem of action and research (Addams, 1910). This contributed to changing the conception of social work from being a philanthropic activity based on good will to being a sciencebased discipline that was socially recognized and legitimized.

As stated by the definition of social work of the International Federation of Social Workers, political advocacy when necessary is included as one of the functions of social workers (IFSW \& IASSW, 2014). The pioneers of social work confirmed the relationship between social work and social policy (Branco, 2016), and currently, authors such as Melissa Bird defend the ethical obligation of the professionals to work in the political arena for social justice and human rights using social work skills (Bird, 2016). At the beginning of the $20^{\text {th }}$ century, Jane Addams was already an example of this dimension of social work.

We stand at a special moment where the extreme right is growing in Europe, fostering situations of racism and discrimination; the human rights of refugees and immigrants are being violated in the course of the actions that are being carried out (Fundamental Rights, 2018). In view of this situation, social work cannot remain immobile, and a strategy to fight for more fair and egalitarian societies is to bring the values and principles of social work into the political sphere. Nevertheless, in many current contexts, engagement in policy practice continues to be little developed by professionals, although it differs in its degree of engagement and its form depending on the country (Gal and Weiss-Gal, 2015).

\section{Aim and Purpose of the Work}

From an analysis of data from books and articles published by Jane Addams, biographies about Jane Addams and scientific articles indexed in the Web of 
Science and Scopus, this article aims to recover the figure of Jane Addams as a political entrepreneur, showing how social work can influence the political sphere. This is done with an analysis of her work for pace defense during the First World War, in a political and social context that was increasingly favorable towards the participation of the United States in that conflict. This analysis also shows how her positioning had negative repercussions on her public image. From this analysis of the figure of Jane Addams, this study shows the importance of being coherent with personal values, taking human rights and social justice as a starting point.

\section{Jane Addams, a Life Dedicated to Social Justice}

Jane Addams is known in social work for establishing the foundations of community and group social work, and she is also recognized in the fields of sociology and public administration for her research and theoretical contributions (Shields, 2017).

Jane Addams founded Hull House in Chicago with Ellen Gates Star in 1889. Jane Addams and Ellen Gates Star founded Hull House after hearing about the Toynbee Hall experience founded in London in 1884 by a couple called the Barnetts (Knight, 2005; Linn, 1935). The knowledge of Jane Addams and Ellen Gates Star allowed them to consolidate the movement of the Settlement Houses in the United States.

At the time of the foundation of Hull House, Chicago was the second largest city in the United States (Linn, 1935) and the sixth largest city in the world (Knight, 2005). Therefore, Chicago underwent constant changes in the social, economic and political spheres (Knight, 2005). Addams and Star established their settlement house in one of the poorest neighborhoods of the city. The neighborhood was experiencing several difficulties, such as serious health problems and bad smells caused, among other things, by garbage and waste that accumulated in the street, which resulted in high rates of infant mortality (Addams, 1910). In addition, families of different nationalities and ethnicities lived together across the city and in the neighborhood in particular (Linn, 1935). The lack of cohesion and communication caused hostility among the families within the community (Shields and Soeters, 2017). Additionally, at that time, the industry was abusing the cheap and disorganized labor force so that women and children were forced to work 12 and 14 hours a day in dangerous environments (Shields and Soeters, 2017). 
Although in Chicago there were already other organizations that worked in the working class neighborhoods to respond to the needs of the community, two elements made Hull House distinct from the other organizations. The first was that it recognized the importance of offering culture - that is, literature and arts to the community - and the second was that it refused to offer religious education (Knight, 2005). In this way, to respond to the needs of the community, not only were services such as a gymnasium, nursery and kindergarten offered, but Hull House also offered numerous activities designed to offer culture and education to the community, such as extension classes, social clubs and groups for training and debate as well as an art gallery that was inaugurated in 1891 (Addams, 1910). These activities encouraged more than 3,000 people to visit Hull House weekly in 1900 (Knight, 1991). All of this enabled Hull House to become a referent space in the city for dialogue, debate and reflection (Addams, 1910; Knight, 1991).

Jane Addams was not alone; she fought alongside other women from different academic levels and disciplines for social justice and human rights. The concept of the settlement house was developed in the United States at a time when women began to attend college and some of them began to participate outside the private sphere. The settlement house offered these women the opportunity to leave their homes, develop their ideas and fight for their ideals and against the problems arising from industrialization (Shields and Soeters, 2017). It was the collaboration of many people that made the activities and the research in Hull House possible; for this reason, Jane Addams never spoke in a self-referential way but always referred to the work they did and the achievements they gained with reference to the residents (Addams, 1910).

Based on arguments that, on the one hand, highlighted the specific virtues of women and, on the other hand, were based on gender equality, these women worked to improve the living conditions of urban women and their families (Kemp and Brandwein, 2010). To this end, together with the neighbors, Hull House worked to improve working conditions in the factories, improve the hygiene of the streets, allow for safe spaces to play and for the separation of adults and children in the judicial system, among other projects (Addams, 1910; Shields, 2017); they worked for the promotion of public health, women's suffrage, and peace and positioned themselves against the legalization of prostitution, considering the prostitutes victims of sexual slavery. 
Specifically, in the struggle for social justice carried out by Hull House, the organization sought for neighbors to help each other and work together (Shields and Soeters, 2017). In addition, the work carried out was guided by three basic principles. These were the participation of and collaborative work with community residents to respond to their needs, respect for the dignity of all people, and, finally, the conception of the causes of poverty and inequality as something structural (Malekoff and Papell, 2012). This means that to fight for social justice, in the settlement houses, it was believed that poverty and social problems transcended individual factors; therefore, to combat these problems, it was necessary not only to work on an individual level but to investigate them as social phenomena (Miranda, 2004). For this, the work done in the settlement houses is summarized in the motto of the three Rs: Residence, Research and Reform (Branco, 2016; Miranda, 2004). In this way, residents in the settlement houses lived with other people in poverty and social exclusion situations to better understand these problems (Addams, 1910).

All of this meant that by the time the study sociology began to spread in Chicago, Hull House was already a space of research and social change, facilitating the close collaboration between some of the professors of the University of Chicago and the residents of Hull House (Shields, 2017).

Hull House became a space for research, training and debate, and a space in which women could participate. Additionally, Hull House had an element that the University of Chicago did not have: direct contact with the community. Although the main objective of Hull House was to contribute to social change and to fight for social justice, it was known that before starting the activities of transformation, it was necessary to investigate such situations (Addams, 1910; Shields, 2017). However, Addams opposed the designation of Hull House as a »sociological laboratory « since, as she explained, »settlements should be something much more human and spontaneous than such a phrase connotes, and yet it is inevitable that the residents should know their own neighborhoods more thoroughly than any other, and that their experiences there should affect their convictions« (Addams, 1910).

An example of this is one of the most well-known studies carried out in Hull House: the House Maps and Papers (1895) (Linn, 1935). In this study, surveys were conducted with the residents of the area, and urban maps were made showing the different nationalities that lived in the neighborhood, as well as the employment of the community members; this prompted the housing law in 1902 (Verde, 2013). Likewise, elements such as the risks 
involved in working at an early age were also analyzed and used to change the laws that regulated child labor (Shields and Soeters, 2017).

Jane Addams's career and the work she did throughout her life allows us to see how there is a coherence between her way of life and her practice as well as between the objectives towards which she worked and what she did to achieve them. Likewise, the actions that she took throughout her life are an example of her coherence as well as her desire for social transformation, community vision and teamwork.

\section{Jane Addams, Coherence in Uncertain Times}

It was because of the Spanish American War in 1898 that Jane Addams began to work on issues related to peace. As a result of this work in relation to peace and war at the international level, Addams published the book Newer Ideals of Peace in 1907 (Pratt, 2004).

From the experiences and knowledge generated in Hull House, Jane Addams developed her ideas of positive peace (Shields and Soeters, 2017), which led her to not limit her work to the neighborhood of Hull House. She understood that her commitment could be extended to everyone (Klosterman and Stratton, 2006). Her experiences at Hull House and her work with people who lived in situations of exclusion and inequality led her to believe that one of the roots of the war was the unfair social order (Sullivan, 1993) and that social change could be achieved from nonviolent cooperation (Deegan, 2010). Her experiences with work and cooperation among different nationalities within Hull House to overcome the difficulties they experienced showed her that coexistence was possible despite the different backgrounds of the people involved (Sullivan, 1993); the prejudices among neighbors of different religions and nationalities would gradually be lost (Linn, 1935). This led her to understand that this could be extended internationally, including into communities around the world that were in a situation of vulnerability as a result of the First World War (Klosterman and Stratton, 2006).

For Addams, peace was not just the absence of war but was positive relationships between family and neighbors as well as at national and international levels; she understood peace as the incorporation of factors such as social justice, democracy and cooperation (Shields, 2017). For Addams, the war contradicted the values and practices that she considered the most progressive in an industrial society (Hutchings, 2017) and showed that real 
progress was only achieved through mutual understanding, something impossible in war (Linn, 1935).

Addams was not alone in that position; for example, as she explained, a group of social workers had met in order to formulate a reaction to the war from those who fought against poverty. All of them, from their experience, knew that a friendly and cooperative relationship was viable and, even though the First World War divided the neighbors of different nationalities, for the social workers, it was unimaginable to make differentiations based on their nationality (Addams, 2002).

At the beginning of the First World War in 1914, there were no international structures that allowed the management of a war on an international level. During the first year of the war, different organizations were formed to defend the negotiating role of the United States in the conflict (Sullivan, 1993), one of which was the Women's Peace Party (WPP), cofounded in 1915 by Jane Addams. This party united the movements for peace and women's suffrage. As at Hull House, the WPP argued that women were committed to the peaceful resolution of conflicts and the improvement of the quality of life of all people (Klosterman \& Stratton, 2006) and that the knowledge that women had about social problems was essential for democracy (Kemp \& Brandwein, 2010). Therefore, the WPP believed that women's suffrage would allow them to incorporate their values into the political sphere and, in this way, move towards a more egalitarian and peaceful society (Kemp \& Brandwein, 2010; Klosterman \& Stratton, 2006; Scott \& Howlett, 2014).

During the First World War, Jane Addams actively participated in numerous acts advocating for peace and in favor of the mediating role of the United States in the war. Among these actions, in March 1915, Jane Addams received an invitation to attend and preside over the International Congress of Women held from April 28 to May 1 of that year in The Hague. Forty-seven women from the United States, most of them members of the Women's Peace Party, accepted the invitation to go to the congress (Addams, 2002; Scott \& Howlett, 2014). Women's voices had been were excluded from discourse and political power, so during the congress, participants argued that exclusion in relation to peace and war was deeply problematic (Shields \& Soeters, 2017), defending, therefore, the importance of women's suffrage (Linn, 1935) and elaborating a document of recommendations to prevent new wars (Sullivan, 1993). The congress allowed the gathering of approximately 1.200 women 
from 12 countries, including both countries that, at that time, were neutral and those that were at war.

Likewise, an International Committee of Women for Permanent Peace (ICWPP), formed by five women from each country who would meet periodically and would work to achieve the objectives established in the congress, was formed. A plan for mediation between countries was also proposed. Within the framework of this plan, 13 women visited the chief statesmen of the main neutral and warring governments. At each visit, the conclusions of the congress were presented, and the application of the peace plan elaborated during the congress was requested. In total, the envoys visited 14 capitols, 21 ministers, two presidents, one king, and Pope Benedict XV (Sullivan, 1993).

As president of The Hague women's congress, Jane Addams was part of one of the committees that visited different European countries and met with foreign ministers, chancellors and prime ministers and other parliamentarians from 9 countries. During their trip, they were also able to meet with members of organizations and civilians that allowed them to get to know the realities of the warring belligerent countries. This knowledge enabled the committee members to publish information on the situation of the countries in the war for different audiences (Sullivan, 1993). Likewise, Addams, Balch and Hamilton shared their experiences and exposed their perceptions and reflections in the book Women at the Hague (Addams, Balch \& Hamilton, 1915).

Jane Addams's struggle for peace did not end with the armistice; until her death, Jane Addams worked for peace internationally (Knight, 2005). At the end of the war, the Women's Peace Party was absorbed by the Women's International League for Peace and Freedom (WILPF), and Jane Addams was elected president of the organization.

Jane Addams' defense of peace shows us how, over the years, her personal life developed into a political life as she became increasingly involved in political activities (Anders \& Da Silveira Nunes Dinis, 2015). Because of her lifelong work in the fight against poverty and in the defense of social justice, Jane Addams has been analyzed as a citizen leader (Anders \& Da Silveira Nunes Dinis, 2015).

From the time of the First World War on, Jane Addams actively participated in the political arena, becoming a policy entrepreneur (Mintrom $\&$ Norman, 2009) thus, with an understanding of the political entrepreneur as 
a person who brings new ideas into the political arena, making the policy change possible (Hogan \& Feeney, 2012). This is what Jane Addams did: she worked in the political arena to advocate for the United States taking a mediating role during the First World War, defending peace not only in the United States but also across the world.

\section{Struggle for Peace: Repercussions of her Positioning}

Her belief in the idea of positive peace led Jane Addams to position herself against the participation of the United States in the First World War and to work with other women towards dialogue and mediation in the conflict. She positioned herself openly and acted to achieve her goals as a political entrepreneur.

Between 1909 and 1915, Jane Addams reached the peak of her popularity (Franklin, 1986), becoming a well-known and respected activist and author due to her work at Hull House (Sullivan, 1993). However, her position against the First World War caused a change in her reputation.

One of the reasons for the attack she received is that the defense of social rights was socially well regarded for a woman of her origin; however, when she focused her efforts on the struggle for peace-she entered an area that was socially reserved for men (Klosterman \& Stratton, 2006). When Addams entered the public and political sphere, which was traditionally reserved for men, she began to be criticized. However, for her, the struggle for peace was related to the struggle for social justice-they were two areas that were connected (Shepler \& Mattina, 2012), and she had been working towards achieving both throughout her live.

Additional criticisms she received were due to statements that Addams expounded on her return from Europe. Specifically, during her European tour following the Conference of Women in The Hague, Addams had the opportunity to talk with soldiers, nurses and civilians who exposed the difficulties and incongruities with which soldiers lived in the trenches, where they had to shoot other men whom, in time of peace, they would have respected. They told her that the use of alcohol and other substances was common during the battle (Addams, 2017). These statements caused her to be severely reviled for attacking the courage of young soldiers (Hutchings, 2017; Linn, 1935). As stated by Addams (Addams, 2002), during the First World War, she saw how, when United States engaged in the war, the tendency was 
to feel admiration for the soldiers that fought and contempt for those people who stated that the fight was unnecessary, the latter being considered traitors and cowards. Likewise, the pacifist movement was accused of wanting to isolate the United States from the rest of the world (Addams, 2002).

Addams was not alone, as there were many women and men who positioned themselves against the war, and many of them received strong reprisals for their position. There were several people who suffered repercussions for their position in favor of peace. Among the women who participated in the International Women's Congress for Peace and Freedom in The Hague, for example, the women from warring countries faced great opposition; delegates from France, Russia and Japan were not able to attend, and the British government refused to issue 130 passports, so that which only 3 women from the UK came to the conference and 28 delegates from northern Germany were imprisoned upon their return (Sullivan, 1993). In the case of the United States, 43 delegates attended, led by Jane Addams. Although at that time the United States was a neutral country, the delegates were ridiculed by President Theodore Roosevelt (Sullivan, 1993) and after returning from The Hague congress, Addams had her first experience in which journalists distorted and calumniated the pacifist movement to discredit it; for her, this was an inevitable consequence of the situation and part of the patriotic duty of journalists (Addams, 2002).

For years, she suffered reprisals from the press and her fellow citizens for her positioning (Shields, 2017), and these reprisals did not end with the armistice. After the war, Addams continued her struggle for peace and social justice. Among the reprisals she suffered during the 1920s, she was attacked for her collaboration in providing food and clothing to the Germans (Klosterman and Stratton, 2006). Additionally, in 1920, a four-volume work entitled Revolutionary Radicalism was published. As Scott and Howlett exposed, »the report targeted (and erroneously conflated) 'pacifism,' socialism, communism, and syndicalism« (Scott \& Howlett, 2014, p. 25). Additionally, the main author of the report, Archibald E. Stevenson, testified before the Overman Committee, giving the names of 62 people who opposed the First World War, among which was the name of Jane Addams (Scott \& Howlett, 2014).

In addition, after the war, she continued to head the Women's International League for Peace and Freedom (WILPF), which was added to the military intelligence bureau's who's who list of pacifists and radicals; the group was 
under government surveillance and members were followed by detectives (Sullivan, 1993). Additionally, after the war, there was an anti-immigrant movement that accused Jane Addams of being unpatriotic, as she fought for the rights of immigrants (Anders \& Da Silveira Nunes Dinis, 2015).

However, despite the criticisms and pressures, she did not stop fighting for pacifism; she and the other pacifist women wanted to change the course of events (Addams, 2002), and their positioning was oriented towards positioning the United States as an engine for a coordinated international policy at a time when political and social issues already had an international character. Although she remained firm in her positions, Addams felt the pressure of going against the tide because she would not renounce her pacifist ideas; as she explained, »the force of the majority was so overwhelming that it seemed not only impossible to hold one's own against it, but at moments absolutely unnatural, and one secretly yearned to participate in 'the folly of all mankind' « (Addams, 2002).

Finally, during the Great Depression, criticism of Jane Addams diminished and her work was recognized; she was awarded the Nobel Prize for Peace in 1931 (Klosterman \& Stratton, 2006). After her death in 1935, Addams was once again recognized and respected for the work she had done throughout her life (Misztal, 2009).

\section{Conclusions}

Throughout her life, Jane Addams was committed to human rights and social justice. She remained consistent with her values and with what she had learned through her work at Hull House and from all those people with whom she had worked. This coherence was manifested in the actions that she carried out throughout her life, including her work in Hull House and her struggle for peace during the First World War, always working towards the same goal: the fight against poverty and for the peace. However, the coherent morality of Jane Addams not only permeated the actions she took but also the manner in which she took those actions. In this way the coherence of Addams can be observed in elements such as the recognition of her errors and ethical dilemmas and in the recognition of all the people who collaborated with her (Addams, 1910).

This coherence was also present in the operation of Hull House, the way to carry out social intervention, it was characterized by the use of dialogue, 
debate and reflection (Addams, 1910; Knight, 1991). At present these are key elements in dialogic learning (Ramis, 2018), a theory of learning that incorporates contributions from social science's outstanding authors, such as Freire's theory of dialogic action (Aiello et al., 2020; Freire, 1970). Currently, dialogic learning contributes to breaking the cycles of poverty of groups that are living in situations of poverty and exclusion, such as the Roma people in Spain (Aiello, Amador, Munté \& Sordé, 2019; Gómez, Padrós, Ríos, Mara and Pukepuke, 2019; Munté, de Vicente, Matulic and Amador, 2020).

In the last decades of the twentieth century, there was a dialogical shift in all areas of society (Gómez, 2019), thus underlining the ability of subjects to influence systems with the aim of transforming them (Giddens, 1984; Habermas, 1984). In this context, social work must work to promote social change based on the principles of »social justice, human rights, collective responsibility and respect for diversities «, as specified in the definition of social work elaborated by the IFSW (IFSW \& IASSW, 2014).

As Jane Addams showed us, one of the ways to achieve this objective is active participation in the formulation of policies. She showed us how, from social work, we can take a step forward and enter the political arena to defend human rights and social justice. Addams and her colleagues worked for peace, not only in the United States but also around the world; they defended the right of all people to live in contexts free of violence. This fight led her to be named Chair of the International Congress of Women in The Hague, assuring her a place in the international scene (Shields \& Soeters, 2017). Despite the threats and the hostile climate they faced, pacifists continued to defend the need for the press to be free, the importance of mediation in the resolution of conflicts and the important role of the community as a mechanism to fight against isolation and work for solidarity (García-Raga, Alguacil \& Boqué, 2019; Mešl, 2018; Sullivan, 1993).

Even though progress has been made in promoting and defending social rights in recent decades, there are still situations of inequality and social exclusion, and answers for these problems in the political sphere continue to be necessary. Rediscovering the figure of Jane Addams and knowing what she accomplished and how she did it allows us to understand the role that social work can have today in the formulation of policies as an engine of change. Additionally, as in the struggle for peace, as shown by Jane Addams, this process sometimes involves many obstacles and can make us the object of criticism and slander. However, as Addams did, we must remain firm and 
375 Melgar, Plaja, Munté \& Redondo - Jane Addams

coherent with our values from social work in the defense of social justice and human rights.

\section{References}

Addams, J. (1910). Twenty Years at Hull-House with Autobiographical Notes. New York: The Macmillan Company.

Addams, J. (2002). Peace and Bread in Time of War. Urbana and Chicago: University of Illinois Press.

Addams, J. (2017). The Revolt Against War (1915). In P. M. Shields (Ed.), Jane Addams: Progressive Pioneer of Peace, Philosophy, Sociology, Social Work and Public Administration (pp. 159-169). Springer.

Addams, J., Balch, E. G. \& Hamilton, A. (1915). Women at the Hague: The international Congress of Women and its Results. The Macmillan Company.

Aiello, E., Amador-López, J., Munté-Pascual, A., \& Sordé-Martí, T. (2019). Grassroots Roma Women Organizing for Social Change: A Study of the Impact of 'Roma Women Student Gatherings'. Sustainability, 11(15), 4054. http://doi.org/10.3390/su11154054

Aiello, E., Donovan, C., Duque, E., Fabrizio, S., Flecha, R. Holm, P., Molina, S., Oliver, E. and Reale, E. (2020). Effective strategies that enhance the social impact of social sciences and humanities research, Evidence \& Policy, vol xx, no xx, 116. https://doi.org/10.1332/174426420X15834126054137

Anders, K. L. \& Da Silveira Nunes Dinis, M. C. (2015). Demonstrating Citizen Leadership: A Case Study of Jane Addams. Interdisciplinary Civic and Political Studies, 10(1), 11-20.

Bird, M. (2016). Social Justice Advocacy in the Belly of the Beast: An Illustration of Policy Change for Social Work. Affilia: Journal of Women and Social Work, 31(2), 257-262. https://doi.org/10.1177/0886109915592668

Branco, F. (2016). The circle of social reform: the relationship social worksocial policy in Addams and Richmond. European Journal of Social Work, 19(3-4), 405-419.

https://doi.org/http://dx.doi.org/10.1080/13691457.2015.1084272

Deegan, M. J. (2010). Jane Addams on citizenship in a democracy. Journal 
of Classical Sociology, 10(3), 217-238.

https://doi.org/10.1177/1468795X10371714

Franklin, D. L. (1986). Mary Richmond and Jane Addams : From Moral

Certainty to Rational Inquiry in Social Work Practice. Social Service

Review, 60(4), 504-525. Retrieved from

http://www.jstor.org/stable/30012363

Freire, P. (1970). Pedagogy of the oppressed. London: Continuum

International. Fundamental Rights Report 2018. (2018). Luxembourg. https://doi.org/10.2811/898119

Fundamental Rights (2018) Report 2018. Luxembourg.

https://doi.org/10.2811/898119

Gal, J. \& Weiss-Gal, I. (2015). The "Why" and the "How" of Policy

Practice: An Eight-Country Comparison. British Journal of Social

Work, 45(4), 1083-1101. https://doi.org/10.1093/bjsw/bct179

García-Raga, L.; Alguacil, M., \& Boqué Torremorell, M.C. (2019). La

educación para la paz en las políticas educativas. Un balance histórico

y desafíos de futuro. Social and Education History, 8(3), 298-323.

https://doi.org/10.17583/hse.2019.4164

Giddens, A. (1984). The Constitution of society: outline of the theory of

structuration. Berkeley: University of California Press.

Gómez, A.(2019). Science With and for Society Through Qualitative

Inquiry. Qualitative

Inquiry. https://doi.org/10.1177/1077800419863006

Gómez, A., Padrós, M., Ríos, O., Mara, L.C. \& Pukepuke, T.

(2019). Reaching Social Impact Through Communicative

Methodology. Researching With Rather Than on Vulnerable

Populations: The Roma Case. Frontiers in Education, 4(9).

https://doi.org/10.3389/feduc.2019.00009

Habermas, J. (1984). The theory of communicative action. V.1. Reason and the rationalization of society. Beacon Press.

Hogan, J. \& Feeney, S. (2012). Crisis and Policy Change: The Role of the

Political Entrepreneur. Risk, Hazards \& Crisis in Public Policy, 3(2),

1-24. https://doi.org/10.1515/1944-4079.1108

Hutchings, K. (2017). War and moral stupidity. Review of International

Studies, 1-18. https://doi.org/10.1017/S0260210517000274

IFSW \& IASSW. (2014). Global Definition of Social Work.

http://ifsw.org/policies/definition-of-social-work/ 
Kemp, S. P. \& Brandwein, R. (2010). Feminisms and Social Work in the United States: An Intertwined History. Affilia: Journal of Women and Social Work, 25(4), 341-364.

https://doi.org/10.1177/0886109910384075

Klosterman, E. M. \& Stratton, D. C. (2006). Speaking Truth to Power Jane Addams' s Values Base for. Affilia: Journal of Women and Social Work, 21(2), 158-168. https://doi.org/10.1177/0886109905285842

Knight, L. W. (1991). Jane Addams and Hull House: Historical Lessons on Nonprofit Leadership. Nonprofit Management and Leadership, 2(2), $125-141$.

Knight, L. W. (2005). Citizen: Jane Addams and the Struggle for

Democracy. (U. O. C. Press, Ed.). Chicago.

Linn, J. (1935). Jane Addams: A Biography. Appleton-Century Company.

Malekoff, A. \& Papell, C. P. (2012). Remembering Hull House, Speaking to Jane Addams, and Preserving Empathy Remembering Hull House , Speaking to Jane. Social Work with Groups, 35(4), 306-312.

https://doi.org/10.1080/01609513.2012.673086

Mešl, N. (2018). Collaborative Social Work in the Communitu with Families Facins Multiple Challenges. Annual of social work, 25(3), 343-367. https://doi.org/10.3935/ljsr.v25i3.215

Mintrom, M. \& Norman, P. (2009). Policy Entrepreneurship and Policy Change. The Policy Studies Journal, 37(4), 649-668.

Miranda, M. (2004). De la caridad a la ciencia. Pragmatismo, Interaccionismo simbólico y Trabajo Social. Mira Editores.

Misztal, B. A. (2009). A Nobel Trinity: Jane Addams , Emily Greene Balch and Alva Myrdal. American Sociologist, 40, 332-353.

https://doi.org/10.1007/s12108-009-9081-2

Munté, A.; de Vicente, I.; Matulic, V.; \& Amador, J. (2020). The invisible feminist action of Roma families. Affilia. https://doi.org/10.1177/0886109920906780

Pratt, S. L. (2004). Jane Addams: Patriotism in Time of War. Midwest Studies in Philosophy, 28(1), 102-118. https://doi.org/10.1111/j.14754975.2004.00085.x

Ramis, M.M. (2018). Contributions of Freire's Theory to Dialogic Education. Social and Education History, 7(3), 277-299. http://dx.doi.org/10.17583/hse.2018.3749

Richmond, M. E. (1917). Social Diagnosis. Russell Sage Fundation. 
Scott, H. B. \& Howlett, C. F. (Eds.). (2014). Antiwar Dissent and Peace Activism in World War I America. University of Nebraska Press. https://doi.org/10.2307/j.ctt1d9nmnk

Shepler, S. R. \& Mattina, A. F. (2012). Paying the Price for Pacifism: The Press's Rhetorical Shift from" Saint Jane" to" The Most Dangerous Woman in America". Feminist Formations, 24(1), 154-171. https://doi.org/10.1353/ff.2012.0002

Shields, P. M. (Ed.). (2017). Jane Addams: Progressive Pioneer of Peace, Philosophy, Sociology, Social Work and Public Administration. Springer. https://doi.org/10.1007/978-3-319-50646-3

Shields, P. M. \& Soeters, J. (2017). Peaceweaving : Jane Addams , Positive Peace, and Public Administration. American Review of Public Administration, 47(3), 323-339. https://doi.org/10.1177/0275074015589629

Sullivan, M. (1993). Social Work's Legacy of Peace: Echoes from the Early 20th Century. Social Work, 38(5), 513-520.

Torras-Gómez, E., Guo, M., \& Ramis, M.M. (2019). Sociological Theory from Dialogical Democracy. International and Multidisciplinary Journal of Social Sciences, 8(3), 216-234. https://doi.org/10.17583/rimcis.2019.4919

Verde, C. (2013). Hull House la ciencia al servicio de la reforma social. In Hull house: el valor de un centro social (pp. 19-44). Paraninfo. 
379 Melgar, Plaja, Munté \& Redondo - Jane Addams

Patricia Melgar Alcantud: Universitat de Girona (España)

ORCID ID: https://orcid.org/0000-0002-2278-4569

Teresa Plaja: Universitat de Barcelona (España)

ORCID ID: https://orcid.org/0000-0003-4752-4912

Ariadna Munté: Universitat de Barcelona (España)

ORCID ID: https://orcid.org/0000-0002-2226-634X

Gisela Redondo: Universitat Rovira i Virgili (España)

ORCID ID: https://orcid.org/0000-0003-2240-7795

Contact Address: gisela.redondo@urv.cat 